World Petroleum Resources Project

\title{
Assessment of Potential Shale Oil and Tight Sandstone Gas Resources of the Assam, Bombay, Cauvery, and Krishna-Godavari Provinces, India, 2013
}
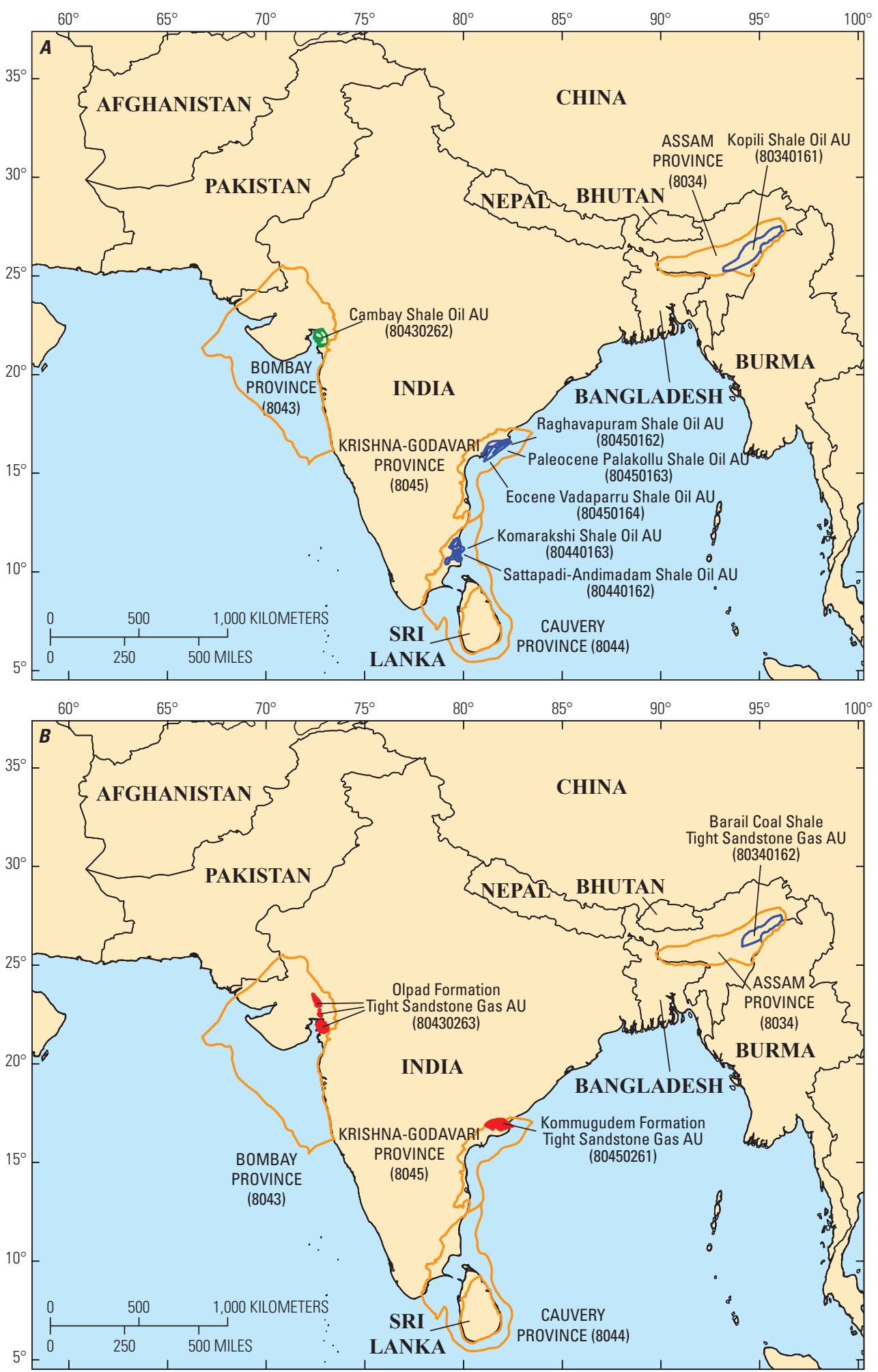

Using a well performance-based geologic assessment methodology, the U.S. Geological Survey estimated a technically recoverable mean volume of 62 million barrels of oil in shale oil reservoirs, and more than 3,700 billion cubic feet of gas in tight sandstone gas reservoirs in the Bombay and KrishnaGodavari Provinces of India.* Shale oil and tight sandstone gas reservoirs were evaluated in the Assam and Cauvery Provinces, but these reservoirs were not quantitatively assessed.

*The term "provinces" refer to geologically defined units assessed by the USGS for the purposes of this report and carries no political or diplomatic connotation.

\section{Introduction}

The U.S. Geological Survey (USGS), in cooperation with the U.S. Department of State, is assessing the potential for unconventional oil and gas resources (shale gas, shale oil, tight sandstone gas, and coalbed gas) in priority geologic provinces worldwide. This report summarizes the geologic models and assessment of potential shale oil and tight sandstone gas resources of geologic provinces in India. Assam, Bombay, Cauvery, and Krishna-Godavari Provinces, and the unconventional reservoirs they contain, are located along the margins of the Indian subcontinent (fig. $1 A$ and $B$ ). Figure $1 A$ and $B$ show the locations

Figure 1. Location of the Assam, Bombay, Cauvery, and Krishna-Godavari Provinces in India (orange). $A$, areas of the shale oil assessment units (AU) that were assessed (solid green area) and evaluated, but not assessed (blue outlines) in this study. $B$, areas of the tight sandstone gas assessment units (AU) that were assessed (solid red areas) and evaluated, but not assessed (blue outlines) in this study. Maps of AUs were based on data from the Directorate General of Hydrocarbons (written commun., 2009). 
of assessed and unassessed shale oil and tight sandstone gas assessment units (AUs), respectively. Unconventional reservoirs in the Ganga Basin and the Damodar Valley area within the Gondwana basins (not shown on fig. 1) were considered, but not evaluated in the study because of insufficient data.

Reservoirs with the greatest potential for containing undiscovered oil and gas resources were assessed. Geologic criteria were developed to evaluate shale oil and tight sandstone gas reservoirs including: (1) average total organic carbon (TOC) content 2.0 weight percent or more; (2) presence of Type I, II, or IIS as the main kerogen type within the source rock for shale oil, and Type III (coal) for tight sandstone gas; (3) net thickness of organic-rich intervals 15 meters or more; (4) adequate thermal maturity for oil and gas generation; (5) presence of abnormally pressured reservoirs; and (6) evidence of oil or gas storage capacity in the rocks. All of these criteria must be present at one place to continue with an assessment (Charpentier and Cook, 2011).

For each of the assessed provinces, variations in the organic-rich shales, types of kerogen, storage potential, and thermal maturity for oil and gas generation are subject to significant geologic uncertainty. Consequently, unconventional accumulations in the United States were used as geologic and engineering analogs to assess these provinces (Charpentier and

Table 1. Key assessment data for shale oil and tight sandstone gas assessment units in India. Average estimated ultimate recovery (EUR) per well, average drainage area, and future success ratios are from United States analogs. Areas of AUs were calculated from maps and data provided by the India Directorate General of Hydrocarbons (written commun., 2009).

[MMBO, million barrels of oil; BCFG, billion cubic feet of gas; $\mathrm{AU}$, assessment unit. Central tendencies are modes except for average EUR, which is median]

\begin{tabular}{|l|r|r|r|r|}
\hline \multirow{2}{*}{ Assessment input data } & \multicolumn{4}{|c|}{ Cambay Shale 0il AU } \\
\cline { 2 - 5 } & Minimum & Mode/Median & Maximum & Calculated mean \\
\hline Potential production area of AU (acres) & 262,500 & 394,000 & 525,000 & 393,833 \\
\hline Average drainage area of wells (acres) & 200 & 250 & 350 & 267 \\
\hline Future success ratio (percent) & 50 & 65 & 85 & 67 \\
\hline Average EUR (MMB0) & 0.04 & 0.07 & 0.25 & 0.08 \\
\hline
\end{tabular}

\begin{tabular}{|l|r|r|r|r|}
\hline \multirow{2}{*}{ Assessment input data } & \multicolumn{4}{c|}{ Olpad Formation Tight Sandstone Gas AU } \\
\cline { 2 - 5 } & Minimum & Mode/Median & \multicolumn{1}{c|}{ Maximum } & Calculated mean \\
\hline Potential production area of AU (acres) & 550,000 & $1,156,000$ & $1,270,000$ & 992,000 \\
\hline Average drainage area of wells (acres) & 100 & 120 & 200 & 140 \\
\hline Future success ratio (percent) & 25 & 50 & 80 & 52 \\
\hline Average EUR (BCFG) & 0.2 & 0.6 & 1.4 & 0.64 \\
\hline
\end{tabular}

\begin{tabular}{|l|r|r|r|r|}
\hline \multirow{2}{*}{ Assessment input data } & \multicolumn{4}{|c|}{ Kommugudem Formation Tight Sandstone Gas AU } \\
\cline { 2 - 5 } & Minimum & Mode/Median & \multicolumn{1}{c|}{ Maximum } & Calculated mean \\
\hline Potential production area of AU (acres) & 200,000 & 800,000 & $1,343,000$ & 781,000 \\
\hline Average drainage area of wells (acres) & 100 & 120 & 200 & 140 \\
\hline Future success ratio (percent) & 25 & 50 & 80 & 52 \\
\hline Average EUR (BCFG) & 0.2 & 0.6 & 1.4 & 0.64 \\
\hline
\end{tabular}

Cook, 2011). Analog data from United States accumulations included estimated ultimate recoveries from wells, average drainage areas of wells, and well exploration success ratios. Key assessment input data are listed in table 1.

\section{Geologic Models for Assessment}

\section{Assam Province (Assam-Arakan Basin)}

This province is interpreted to have originated as a Mesozoic (Early Cretaceous) rifted passive margin, but evolved into a foreland basin with fold and thrust belts during the Neogene when the Indian plate collided with the Eurasian continent. The Eocene Kopili Shale was evaluated for shale oil and the Oligocene Barail Coal Shale was evaluated for tight sandstone gas.

The Kopili Shale was deposited in a proximal marine shelf environment. The Kopili Shale and the underlying Sylhet Formation grade laterally into distal marine mudstones and merge below thrust sheets to form the Disang Group. Thrust sheet loading might have sufficiently buried the Disang Group to generate oil and gas. These rocks are considered the main source for oil and gas in conventional accumulations in the province. The extent of the Kopili Shale and retention of hydrocarbons are unknown beneath thrust sheets. This reservoir was not quantitatively assessed because of the significant geologic uncertainty.

The Barail Coal Shale was deposited in a paralic (marginal marine) and nearshore environment and consists of mudstones, carbonaceous mudstones, sandstones, and coal. The geologic extent, depositional facies, and presence of hydrocarbons beneath thrust sheets are unknown. This reservoir was not quantitatively assessed because of the significant geologic uncertainty.

\section{Bombay Province (Cambay Basin)}

The Cambay Basin began as a failed rift in the Late Cretaceous during which time a delta developed and extended southwestward toward the Bombay Shelf. The upper Paleocene to middle Eocene Cambay Shale was evaluated for shale oil, and the Paleocene Olpad Formation was evaluated for tight sandstone gas.

The Cambay Shale was deposited in deltaic and nearshore marine environments in the northern and central parts of the basin, and in more distal marine environments in the southern part of the basin. The formation consists of marine mudstone with some interbedded siltstone and sandstone intervals, coal, and carbonaceous mudstone. The distal marine Cambay Shale in the southern depocenter was quantitatively assessed, but a probability that sufficient oil resources might not be present was estimated. A possibility exists that the oil in conventional 
reservoirs in the Cambay Basin may have migrated a long distance from source rocks farther to the south.

The Olpad Formation was deposited in lacustrine, deltaic, and (or) nearshore marine environments in the northern and central parts of the basin. The extents of the Olpad Formation source rocks in the southern and deeper portions of the basin are unknown. The Olpad Formation consists of syn-rift, volcanogenic conglomerates, rock wash (trap wash), sandstones, siltstones, mudstones, claystones, coals, and carbonaceous mudstones. The Olpad Formation was also quantitatively assessed, but has an estimated probability that the sandstone may actually be a conventional reservoir rather than a tight sandstone reservoir.

\section{Cauvery Province (Cauvery Basin)}

This province is a rifted passive margin originating during the Late Jurassic through Early Cretaceous when the India and Sri Lanka landmass separated from Gondwana. The combined Jurassic to Lower Cretaceous Andimadam Formation and Lower to Upper Cretaceous Sattapadi Shale, and the Upper Cretaceous Komarakshi Formation were evaluated for shale oil.

The Andimadam Formation and Sattapadi Shale were both deposited in marine environments, but the lowermost Andimadam section may contain lacustrine mudstones. The two formations are treated as a single assessment unit in this study because the mudstones in the stratigraphic succession are not easily differentiated. The main kerogen type in the mudstones is Type III and a low probability exists for the presence of shale oil reservoirs. These formations were not quantitatively assessed.

The Komarakshi Formation (includes the Kudavasal and Portonovo mudstones) was deposited in a nearshore marine environment. The main kerogen type in these mudstones is Type III and a low probability exists for the presence of shaleoil reservoirs. This formation was not quantitatively assessed.

\section{Krishna-Godavari Province (Krishna-Godavari Basin)}

This province is a rifted, passive margin originating during the late Paleozoic through Early Cretaceous when the India landmass separated from Gondwana. The Cretaceous Raghavapuram Shale, Paleocene Palakollu Shale, and Eocene Vadaparru Shale were evaluated for shale oil. The Permian Kommugudem Formation was evaluated for tight sandstone gas.

The Raghavapuram Shale, Palakollu Shale, and Vadaparru Shale were deposited in marginal marine and shelf environments. The main kerogen type in these mudstones is Type III and a low probability exists for the presence of shale-oil reservoirs. These formations were not quantitatively assessed.

The Kommugudem Formation consists of alternating sandstone and mudstone with coal beds. It was deposited in lagoonal, fluvial, and deltaic environments. Gas is produced from the Kommugudem Formation in the northern onshore part of the Krishna-Godavari Basin. The reservoir might actually be a conventional reservoir based on gas production within the conventional Mandapeta gas field. The Kommugudem Formation was quantitatively assessed, but a low probability exists for the presence of tight sandstone gas reservoirs because the sandstone might not be classified as tight.

\section{Resource Summary}

Only the Cambay Shale, Olpad Formation, and Kommugudem Formation were quantitatively assessed. The assessment units are Cambay Shale Oil, Olpad Formation Tight Sandstone Gas, and Kommugudem Formation Tight Sandstone Gas (table 2).

The results of the USGS assessment of shale oil and tight sandstone gas resources in the Assam, Bombay, Cauvery, and Krishna-Godavari Provinces in India are listed in table 2 . In summary, the estimated mean volumes of technically recoverable petroleum resources are as follows: (1) Cambay Shale Oil AU of the Bombay Province, with an AU probability of 0.8-62 million barrels of oil (MMBO; range, 0 to $135 \mathrm{MMBO}$ ); 169 billion cubic feet of natural gas (BCFG; range, 0 to $365 \mathrm{BCFG}$ ); and $6 \mathrm{MMB}$ of natural gas liquids (MMBNGL; range, 0 to 12 MMBNGL); (2) Olpad Formation Tight Sandstone Gas AU in the Bombay Province, with an AU probability of $0.9-2,101 \mathrm{BCFG}$ (range, 0 to 3,970 $\mathrm{BCFG}$ ) and 21 MMBNGL (range, 0 to 43 MMBNGL); and (3) Kommugudem Formation Tight Sandstone Gas AU of the Krishna-Godavari Province, with an AU probability of 0.9-1,653 BCFG (range, 0 to 3,399 BCFG) and 20 MMBNGL (range, 0 to $43 \mathrm{MMBNGL}$ ). The ranges of resource estimates for these unconventional resources reflect the considerable geologic uncertainty in these AUs.

Assessment units for Kopili Shale Oil, Barail Coal Shale Tight Sandstone Gas, Sattapadi-Andimadam Shale Oil, Komarakshi Shale Oil, Raghavapuram Shale Oil, Paleocene Palakollu Shale Oil, and Eocene Vadaparru Shale Oil were identified (table 2), but not quantitatively assessed because of the significant geologic uncertainty.

\section{Acknowledgments}

The authors are grateful for the data and consultation from the India Ministry of Petroleum and Natural Gas and its agencies. The India Directorate General of Hydrocarbons (DGH) provided much of the data used in this study. Valuable data and contributions were also provided by Oil India, Limited (OIL); Gas Authority of India, Limited (GAIL); and Oil and Natural Gas Corporation (ONGC).

We thank Mr. Chandra Bhan Singh, Indian Ministry of Petroleum and Natural Gas, and Mr. S.K. Srivastava, Director General of the Directorate General of Hydrocarbons (DGH). Mr. Sanjay Chawla, Head, Alternate Energy; Mr. Atanu Banerjee, Geologist; Mr. S.C. Sarma, Head, Shale Gas Programme; and Mr. Malcom Lall, National and International Cooperation and Technical Coordinator, DGH, were particularly helpful by sharing information and insights that gave a better understanding of the petroleum geology and unconventional oil and gas resource potential of the basins in India prior to the USGS assessment.

The authors are grateful for the coordination and logistical help provided by the U.S. Department of State, particularly Mr. Joseph Figueiredo, Ms. Chung Joon Lee, Ms. Angie Mizeur, Mr. David S. Williams, and Mr. Jason A. Donovan. 
Table 2. Assessment results for potential shale oil and tight sandstone gas resources in India (technically recoverable, unconventional resources).

[MMBO, million barrels of oil; BCFG, billion cubic feet of gas; MMBNGL, million barrels of natural gas liquids. Results shown are fully risked estimates. For gas fields, all liquids are included under the natural gas liquids (NGL) category. F95 denotes a 95-percent chance of at least the amount tabulated, F50 denotes a 50-percent chance, and F5 denotes a 5-percent chance. TPS, total petroleum system; AU, assessment unit. Gray shading indicates not applicable]

\begin{tabular}{|c|c|c|c|c|c|c|c|c|c|c|c|c|c|c|}
\hline \multirow{3}{*}{$\begin{array}{c}\text { Geologic provinces, total petroleum } \\
\text { systems (TPS), and assessment } \\
\text { units (AU) }\end{array}$} & \multirow{3}{*}{$\begin{array}{c}\text { AU } \\
\text { prob- } \\
\text { ability } \\
\end{array}$} & \multirow{3}{*}{$\begin{array}{l}\text { Field } \\
\text { type }\end{array}$} & \multicolumn{12}{|c|}{ Total undiscovered resources } \\
\hline & & & \multicolumn{4}{|c|}{ Oil (MMBO) } & \multicolumn{4}{|c|}{ Gas (BCFG) } & \multicolumn{4}{|c|}{ NGL (MMBNGL) } \\
\hline & & & $\mathrm{F95}$ & $\mathrm{F} 50$ & $\mathrm{F5}$ & Mean & $\mathrm{F95}$ & F50 & F5 & Mean & F95 & F50 & $\mathrm{F} 5$ & Mean \\
\hline \multicolumn{15}{|c|}{ Assam Province, Cenozoic Composite TPS, 803401} \\
\hline Kopili Shale Oil AU, 80340161 & \multicolumn{14}{|c|}{ Not quantitatively assessed } \\
\hline $\begin{array}{l}\text { Barail Coal Shale Tight Sandstone } \\
\text { Gas AU, } 80340162\end{array}$ & \multicolumn{14}{|c|}{ Not quantitatively assessed } \\
\hline \multicolumn{15}{|c|}{ Bombay Province, Cenozoic Composite TPS, 804302} \\
\hline Cambay Shale Oil AU, 80430262 & 0.8 & Oil & 0 & 63 & 135 & 62 & 0 & 170 & 365 & 169 & 0 & 6 & 12 & 6 \\
\hline $\begin{array}{l}\text { Olpad Formation Tight Sandstone } \\
\text { Gas AU, } 80430263\end{array}$ & 0.9 & Gas & & & & & 0 & 2,067 & 3,970 & 2,101 & 0 & 20 & 43 & 21 \\
\hline \multicolumn{15}{|c|}{ Cauvery Province, Mesozoic-Cenozoic Composite TPS, 804401} \\
\hline $\begin{array}{l}\text { Sattapadi-Andimadam Shale Oil AU, } \\
80440162\end{array}$ & \multicolumn{14}{|c|}{ Not quantitatively assessed } \\
\hline Komarakshi Shale Oil AU, 80440163 & \multicolumn{14}{|c|}{ Not quantitatively assessed } \\
\hline \multicolumn{15}{|c|}{ Krishna-Godavari Province, Mesozoic-Cenozoic Composite TPS, 804501} \\
\hline $\begin{array}{l}\text { Raghavapuram Shale Oil AU, } \\
80450162\end{array}$ & \multicolumn{14}{|c|}{ Not quantitatively assessed } \\
\hline $\begin{array}{l}\text { Paleocene Palakollu Shale Oil AU, } \\
80450163\end{array}$ & \multicolumn{14}{|c|}{ Not quantitatively assessed } \\
\hline $\begin{array}{l}\text { Eocene Vadaparru Shale Oil AU, } \\
80450164\end{array}$ & \multicolumn{14}{|c|}{ Not quantitatively assessed } \\
\hline \multicolumn{15}{|c|}{ Krishna-Godavari Province, Paleozoic Composite TPS, 804502} \\
\hline $\begin{array}{l}\text { Kommugudem Formation Tight } \\
\text { Sandstone Gas AU, } 80450261\end{array}$ & 0.9 & Gas & & & & & 0 & 1,573 & 3,399 & 1,653 & 0 & 18 & 43 & 20 \\
\hline Total shale oil resources & & & & & & 62 & & & & 169 & & & & 6 \\
\hline Total tight sandstone gas resources & & & & & & & & & & 3,754 & & & & 41 \\
\hline
\end{tabular}

\section{Reference}

Charpentier, R.R., and Cook, T.A., 2011, USGS methodology for assessing continuous petroleum resources: U.S. Geological Survey Open-File Report 2011-1167, 73 p.

\section{For Further Information}

Supporting geologic studies of total petroleum systems and assessment units, and reports on the methodology used in the assessment of the Assam, Bombay, Cauvery, and Krishna-Godavari Provinces, are in progress. Assessment results are available at the USGS Energy Resources Program Web site: http://energy.usgs.gov/OilGas/ AssessmentsData/WorldPetroleumAssessment.aspx.

\section{Indian Provinces Assessment Team}

Timothy R. Klett, Christopher J. Schenk, Craig J. Wandrey, Michael E. Brownfield, Ronald R. Charpentier, Marilyn E. Tennyson, and Donald L. Gautier. 